\title{
Child Labour in India - Present Scenario:
}

\author{
Dr. D.Kumuda \\ Associate Professor, Department Of Economics, Opp R.T.O, Bangarpet Road, \\ Bangalore University, Kolar-563101, Karnataka
}

\begin{abstract}
The Children Of Today Are The Future Of Tomorrow; This Powerful Statement Assumes Special Significance In Our Context As Children (0-14 Years) Comprise One Third Of The Total Population In The Country. Every Child, On Provision Of A Conducive And An Enabling Environment, May Blossom Into An Ever Fragrant Flower, To Shine In All Spheres Of Life. This Reminds Us Of The Onerous Responsibility That We Have To Mould And Shape Their Present Conditions In The Best Possible Way.

The Journey In The Life Cycle Of A Child Involves The Critical Components Of Child Survival, Child Development And Child Protection. Child Participation Which Envisages Their Active Involvement And Say In The Entire Process Adds A New Dimension. Child Survival Entails Their Basic Right Of Being Born In A Safe And Non-Discriminatory Environment And Grows Through The Formative Years Of Life In A Healthy And Dignified Way. Adverse Sex Ratio At Birth, High Child Mortality Rates And The Rapidly Declining Child Sex Ratio Reflects The Ensuing Challenges. Reducing The Level Of Malnutrition And Micronutrient Deficiency And Increasing Enrolment, Retention, Achievement And Completion Rates In Education Are The Focus Areas In Child Development. Safeguarding The Children From Violence, Exploitation And Abuse Fall Under Child Protection.
\end{abstract}

Key Words: Introduction, Status, Objectives, Working Situation, Data Analysis, Conclusion.

\section{Introduction}

Every child is a gift of God -a gift must be nurtured with care and affection, with in the family and society. But unfortunately due to socio-economic and cultural problems, the code of child centeredness was replaced by neglect, abuse and deprivation, particularly in the poverty afflicted sections of the society. While child labour is a complex problem that is basically rooted in poverty. The strategy of progressive elimination of child labour underscores India's legislative intent, and takes cognizance of the fact that child labour is not an isolated phenomenon that can be tackled without simultaneously taking into account the socio-economic milieu that is at the root of the problem. An International Moral Code of Right and Wrong Behavior said that "human rights and fundamental freedoms are the birthright of all human beings" and as a result such rights may neither be granted nor be taken away by legislation.

The position of India in terms of child labour is not an appreciable one; with a credible estimates ranging from 60 to 115 million, India has the largest number of working children in the world. Whether they are sweating in the heat of stone quarries, working in the fields 16 hours a day, picking rags in the city streets, or hidden away as domestic servants, these children endure miserable and difficult lives. They earn little and are made to work more. They struggle to make enough to eat and perhaps to help feed their families as well.

Child labour is a conspicuous problem in India. Its prevalence is evident in the child work participation rate, which is more than that of other developing countries. Poverty is the reason for child labour in India. The meager income of child labourers is also absorbed by their families. The paucity of organized banking in the rural areas creates a void in taking facilities, forcing poor families to push their children in harsh labour, the harshest being bonded labour. That declaration stated that all ILO members have an obligation "to respect, to promote and to realize in good faith" a set of fundamental rights which include freedom of association the effective recognition of the right to collective bargaining the elimination of all forms of forced or compulsory labour the effective abolition of child labour and the elimination of discrimination in respect of employment and occupation. Millions of children in India today turned into child labor due to various socio-economic problems. According to one study, more than a quarter of the World's total number of child laborers are in India and every third household in the country has a child labor.

The following objectives has undertaken for the study;

\section{Objectives}

- The main objective of presented paper is to understand the poor situation of children in India.

- To find out the causes, effect and present condition of child Labour in India.

- To find out the present distribution of child Labour in India. 
A survey points out child labor is predominant in low technology traditional industries like carpetmaking, lock-industry, matches and fireworks industry, stone quarries, mines fishing. Many of them are regarded as high hazards job.

\section{Where Are Children Employed?}

According to a report titled "Children in India 2012 - A Statistical Appraisal", released by the Ministry of Statistics and Programme Implementation (MOSPI), India has the largest number of child labourers (under14 years of age) in the world. The Census 2001 also found that nearly $85 \%$ of child labourers are hard-to-reach, invisible and excluded population as they work largely in the unorganized sector, both rural and urban, within the family or in household-based units.

According to the MOSPI report, children are engaged in:

- Agriculture

- Hazardous industries / occupations

- Small industrial workshops and service establishments

- On the streets; and

- Domestic work

The major occupations involving child labour are pan, bidi and cigarettes (21\%), construction (17\%), and spinning \& weaving $(11 \%)$, which qualify as hazardous processes/occupations. Domestic workers constitute $15 \%$ of the total child workers.

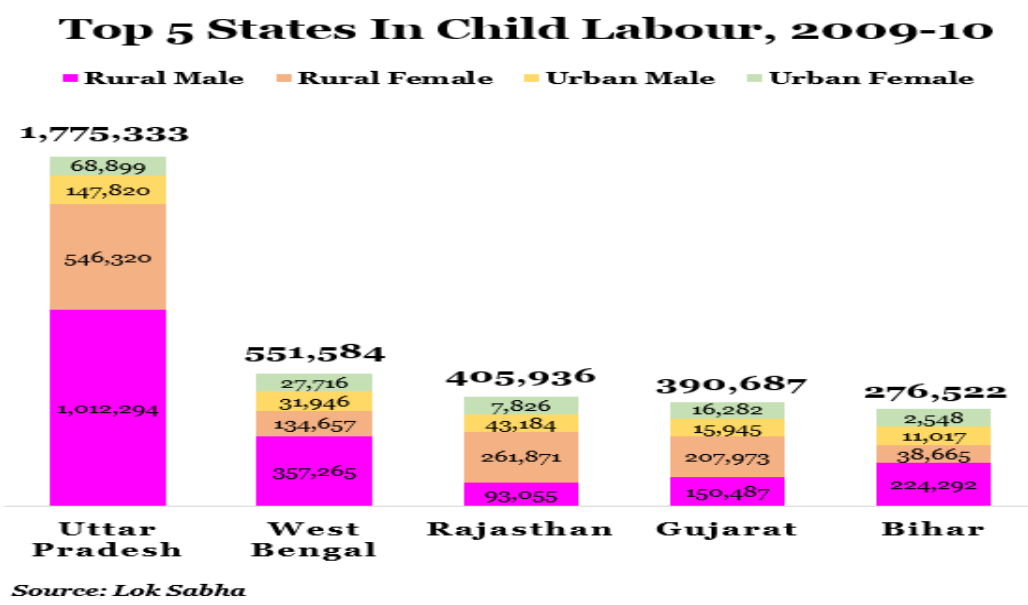

The top five states in Child Labour both Urban and Rural are Uttar Pradesh, West Bengal, Rajasthan, Gujarat, and Bihar.

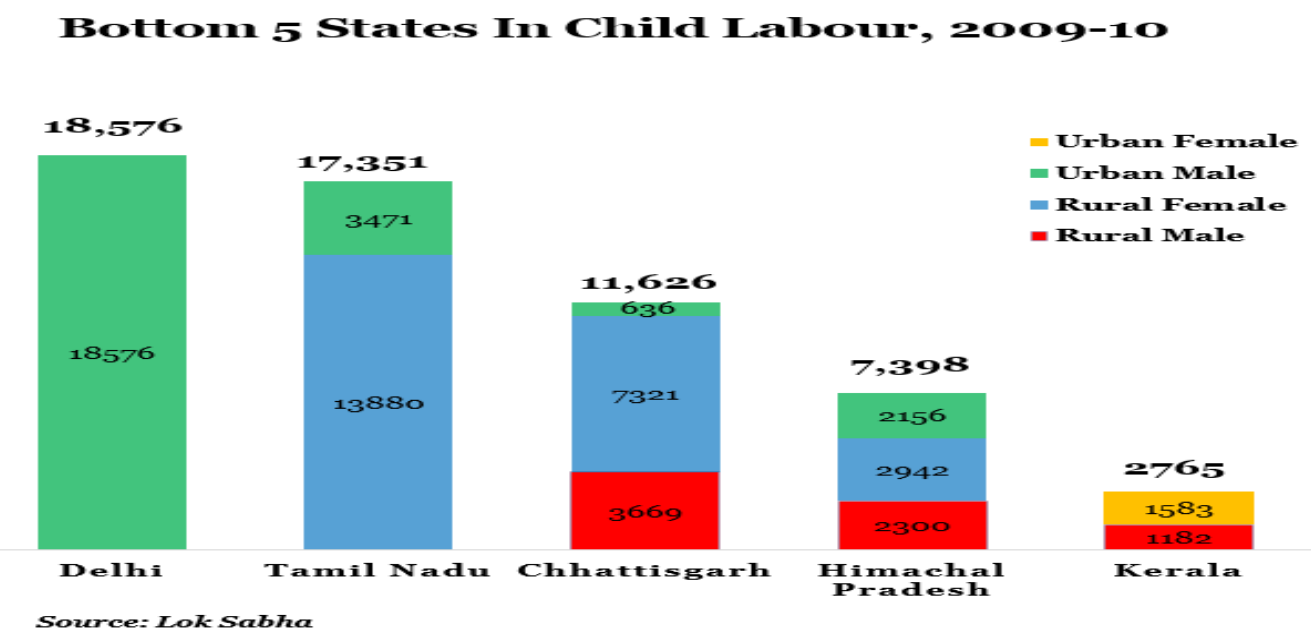

The highest decline in terms of percentage is of Chhattisgarh and Tamil Nadu where child labour dropped by $97 \%$ \& 96\%, respectively. U.P saw the least decrease in numbers $(7.9 \%)$ since 2001 . The decrease in number of children working is an encouraging sign, and suggests the effectiveness of the schemes (direct or indirect like focus on primary school enrollment) implemented by the Government. Though other reasons including social awareness and economic growth could also be playing a role. 


\section{National Child Labour Project}

The National Child Labour Project (NCLP) along with Grant-in-Aid (GIA) are the schemes aimed at rehabilitating child labourers. The programmes are being implemented since 1988. The schemes hope to rehabilitate children withdrawn from working in hazardous occupations/ processes into the formal educational system.

The Government released Rs 137.43 crore as grant for NCLP for the year 2011-12. The states of Uttar Pradesh, West Bengal, Bihar, Orissa and Andhra Pradesh have been the biggest beneficiaries of these funds.

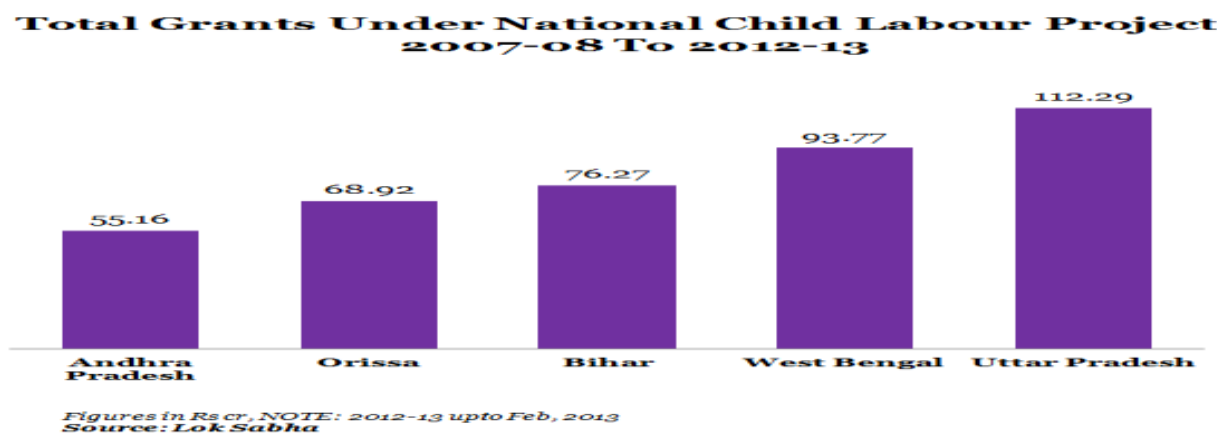

Over 0.4 million children have been mainstreamed under the NCLP scheme since 2009. Of this, the maximum number of children (0.1 million) rehabilitated are from Uttar Pradesh. But the performance of the scheme in West Bengal is not as effective.

West Bengal receives almost twice the amount of funds (Rs. 93.7 crore) under the scheme than states like Madhya Pradesh (Rs. 50.4 crore)and Andhra Pradesh (Rs. 55.1 crore). And when we compare the number of children mainstreamed under the scheme, West Bengal has rehabilitated only 25,975 children while Orissa $(48,506)$ has almost twice the numbers and Madhya Pradesh $(45,669)$ and AP $(36,589)$ are doing a better job.

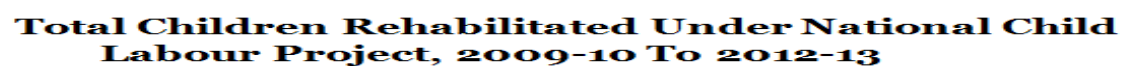

Labour Project, $2009-10$ To $2012-13$

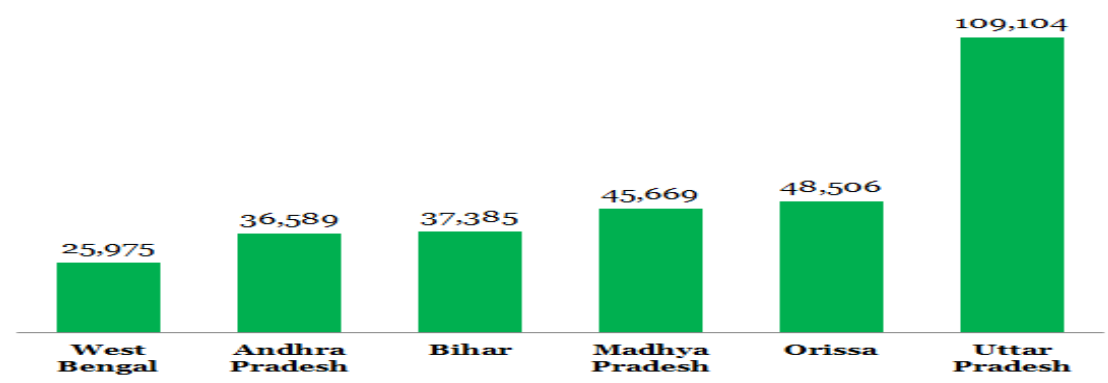

NOTE: $2012-13$ UPto Dec. 2012
Source:LokSabha

IV. Prosecution of Guilty Employers

\begin{tabular}{|l|l|l|l|l|l|l|}
\hline State & \multicolumn{3}{l}{ No. of Inspection } & \multicolumn{2}{l}{ No. of Prosecution } & \multicolumn{2}{l}{ No of Conviction } \\
\cline { 2 - 8 } & $\mathbf{2 0 1 1}$ & $\mathbf{2 0 1 2}$ & $\mathbf{2 0 1 1}$ & $\mathbf{2 0 1 2}$ & $\mathbf{2 0 1 1}$ & $\mathbf{2 0 1 2}$ \\
\hline Punjab & 26,386 & 9,936 & 1,011 & 260 & 478 & 159 \\
\hline Bihar & 11,330 & 7,197 & 1,258 & 716 & & NA \\
\hline Karnataka & 11,593 & 7,174 & 232 & 101 & 48 & 24 \\
\hline Gujarat & 18,442 & 6,863 & 240 & 95 & 41 & 1 \\
\hline Assam & 4,785 & 5,748 & 30 & 112 & 2 & 8 \\
\hline
\end{tabular}

Punjab had the highest number of inspections $(9,936)$ under the Child Labour (Prohibition \& Regulation) Act , 1986 in 2012. It also had the highest number of convictions at 159 followed by U.P with 156 under the Act. 


\section{Conclusion}

Child labour is a deep-rooted problem as it denies the child his/her basic right to education. This, in turn, leads to unskilled adult labour force, which causes early physical decay, economic insecurity, low quality of life and ultimately high poverty.

Child labour is a vicious circle of poverty, unemployment, underemployment and low wages. Over the years, the Government has multiplied its efforts to address the needs and rights of exploited children. The Government grants being released under NCLP have also seen a significant increase, which is translating to a higher number of rehabilitated children joining formal education in most major states. However, the high number of children working (4.9 million) is still worryingly high. Something that should bother not just policy makers but also well-meaning parents everywhere.

\section{References}

[1]. Census of India 2001, Office of The Registrar General and Census Commissioner, India, New Delhi 2006, p. 106. Census of India (2008), Children and Work, Ministry of Labor and Employment, Government of India, p.92

[2]. Children in India 2012 - A Statistical Appraisal, Ministry of Statistics and Programme Implementation, Government of India, New Delhi 2012,p. 70.

[3]. The National Family Health Survey -3, 2005-2006, Mumbai 2007, p.47

[4]. Kombarakaran, F.A. (2004), Street children of Bombay: their stresses and strategies of coping, Children and Youth Services Review 26, p.872

[5]. ILO, United States Policies to Address Child Labour Globally, 2010,p.75

[6]. Children in India 2012 - A Statistical Appraisal, Ministry of Statistics and Programme Implementation, Government of India, New Delhi 2012 